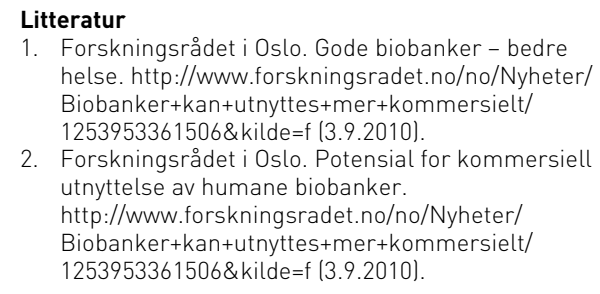

\section{Praktisk om gastrointestinal blødning}

Aurora D. Pryor, Theodore N. Pappas,

Malcolm Stanley Branch, red.

Gastrointestinal bleeding

A practical approach to diagnosis and management. 223 s, tab, ill. Heidelberg:

Springer, 2010. Pris USD 189

ISBN 978-1-4419-1692-1

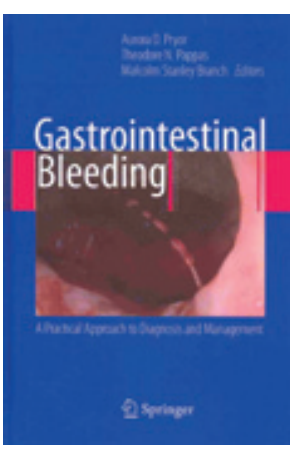

Gastrointestinal

blødning er, tross fallende fore-

komst, fortsatt en utfordring i klinisk praksis og krever en multidisiplinær tilnærming. Selv de mest erfarne endoskopører/ intervensjonister kan bli svette på ryggen under

håndtering av massiv gastrointestinal blødning. Få nye lærebøker innen emnet er blitt utgitt siste tiår, derfor er denne nye boken et kjærkomment tilskudd til litteraturen. Både redaktørene og forfatterne, fra ulike disipliner, arbeider ved Duke University Medical Center, i North Carolina, USA.

Målgruppen er primært leger under utdanning, men også erfarne kirurger, gastromedisinere og radiologer vil finne nyttig kunnskap. Forfatterne har en praktisk tilnærming ved utredning, diagnose og håndtering av gastrointestinal blødning, og boken er enkelt delt i tre seksjoner: øvre og nedre gastrointestinal blødning, samt gastrointestinal blødning fra ukjent fokus. Omtalen av etiologi omfatter et eget avsnitt om uvanlige blødningsårsaker. Foruten sentrale tema som ulcusblødning, oesophagusvariceblødning og kolitt- og tumorblødninger, er også blødning fra gallegang og pancreas omtalt. Kapitlene er logisk og strukturert oppbygd. En kort teoretisk bakgrunn etterfølges av diagnostiske og terapeutiske hovedpunkter med medisinske, kirurgiske og radiologiske momenter. Man gjør rede for risikovurderinger. Radiologisk intervensjon, som har fått en større plass $\mathrm{i}$ behandlingen de senere årene på bekostning av kirurgi, er grundig omtalt. Referansene er relevante og inkluderer sentrale publikasjoner inntil 2009.

Gastrointestinal blødning er i høy grad et praktisk emne. Det er derfor gledelig at innholdet understøttes av mange instruktive bilder (dog av variabel teknisk kvalitet) og tabeller/figurer som gjør boken variert og lett å få oversikt over. De korte kapitlene og formatet inviterer til bruk i hverdagen.

Totalinntrykket er at dette er en bred og meget praktisk gjennomgang av temaet gastrointestinal blødning, og jeg anbefaler boken for alle utdanningskandidater i gastrofaget. Noen aspekter kunne vært bedre belyst, bl.a. kunne selektive serotoninreopptakshemmere vært omtalt i større grad under medikamentårsaker til øvre gastrointestinal blødning. Endelig ville en medfølgende DVD med klipp fra ulike blødningskasus gitt et ytterligere pedagogisk løft.

\section{Tore Grimstad}

Medisinsk avdeling

Stavanger universitetssjukehus

\section{Forskning på barns mentale helse}

Kimberly E. Hoagwood, Peter S. Jensen, Mary McKay et al, red.

Children's mental health research

The power of partnerships. 192 s. Oxford: Oxford University Press, 2009. Pris GBP 35 ISBN 978-0-19-530782-5

Avstanden mellom forskning og praktisk virkelighet kan være stor. Ikke bare tar det år før praksis endres på bakgrunn av empirisk kunnskap, men de problemstillingene forskningen tar opp, kan oppleves lite relevante for praksis. De som står bak denne boken, ønsker å redusere dette problemet. Forskere og brukere må samarbeide for å få bedre forskning om barns psykiske helse, fremhever de. Budskapet er trolig like relevant for andre forskningsfelt.

Både The National Institute of Mental Health i USA og norske myndigheter har som uttalt målsetting å øke brukermedvirkningen både $\mathrm{i}$ behandling og forskning, og denne boken er ment som en hjelp for å nå et slikt mål. Den er først og fremst skrevet for forskere, men vil være nyttig lesning for alle som deltar i et forsker-bruker-samarbeid.

Det er seks kapitler. Først understreker forfatterne behovet for, og rammene for, forsker-bruker-samarbeid. Begrepet «bruker» er vidt, det omfatter familier med barn og ungdom, klinikere som står for tiltak, og representanter for miljøene der barna med problemer, lever. Også de som er med på å forme de ytre rammene for tiltak, politikere og administratorer, oppfattes som brukere av forskningen. I tre av kapitlene beskriver forfatterne behovet for å integrere de ulike brukergruppene i forskningsprosessen. I et femte kapittel beskriver man en rekke konkrete eksempler på brukermedvirkning, mens man i det avsluttende kapitlet igjen understreker hvor avhengig forskerne er av innspill fra brukerne for å gjøre forskningen nyttig og levedyktig. Samarbeidet dreier seg om alt fra å la representantene fra miljøene delta i planleggingen av prosjekter gjennom fokusgrupper, til at brukerne samler inn data eller er ansvarlige prosjektledere.

Den som håper å finne de enkle, entydige oppskriftene, blir skuffet. Skribentene understreker først og fremst problemer som må tas på alvor. Løsningene må dikteres av lokale forhold. Forskning om sensitive forhold skaper spesielle problemer, og mange eksempler handler om tiltak for å redusere problematferd blant barn i problemområder i USA. Gjensidig tillit, anerkjennelse av andres kompetanse, evne til kommunikasjon, vilje til å gi fra seg kontroll og makt og fleksibilitet i metodevalg er sentrale begreper.

Boken er ordrik og preget av mange og ganske generelle gjentakelser, f.eks. om behovet for tillit. Dermed kan man oppleve noen passasjer som kjedelige. Ikke alle problemene er like relevante i Norge som i USA. Men skal man gå i gang med et bruker-forsker-samarbeid, vil boken være nyttig. For det legges ikke skjul på at det ved siden av gode personlige egenskaper kreves holdningsendringer hos forskerne.

\section{Berit Grøholt}

Institutt for klinisk medisin

Universitetet i Oslo

\section{Populært om kvinnehelse}

Gillian McKeith

Women's health

A practical guide to all the stages and ages of the female life cycle. $416 \mathrm{~s}$. London: Penguin Books, 2010. Pris GBP 17 ISBN 978-0-718-15435-6

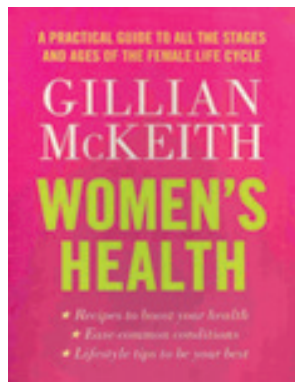

Bøker om kvinners liv og helse er hverdagskost og finnes $i$ alle varianter og på alle språk. Denne boken er skrevet av en klinisk ernæringsfysiolog, Gillian McKeith fra England, og er ifølge henne en «celebration of womanhood». Hensikten er å sette søkelyset på en sunn livsstil for å oppnå et bedre og sunnere liv, og da unngår man ikke klisjeer som «indre fred bringer harmoni til det fysiske, psykiske, psykologiske og følelsesmessige jeget». Det skjemmer litt, men klarer man å overse dette, 
kan boken være nyttig og gi innsikt i kvinners liv på en oversiktlig og grei måte.

Kapitlene inneholder en rekke konkrete opplysninger og helsetips om de fire stadiene i kvinnens liv: pubertet, fertil alder, perimenopause og postmenopause. Temaer som sex $i$ alle aldre, seksuelt overførbare sykdommer, vektøkning i alle aldre, metabolsk syndrom, helsesjekker osv. er skrevet balansert og greit $i$ en lett og kåserende stil. Layouten er tiltalende. Målgruppen er alle som er opptatt av bedre liv og helse. Språket er enkelt, og faguttrykkene forklares i stor grad, men man trenger nok noe basiskunnskap innen medisin og fysiologi for å ha godt utbytte.

Gillian McKeith er ganske kontroversiell i England (og USA), og hennes kvalifikasjoner og ernæringsråd har møtt mye kritikk fra fagfolk. Hun er kanskje best kjent for boken You Are What You Eat (1), som har solgt i millionopplag, og man kan se henne på TV i England, Canada og USA.

Dette er absolutt ingen medisinsk lærebok, men den kan være verdifull på sin måte og kan godt leses av helsepersonell som ønsker en bredere og mer populistisk tilnærming til emnet.

\section{Inger Øverlie}

Bayer Schering Pharma

Oslo

Litteratur

1. McKeith, G. You Are What You Eat. 1. utg. London: Penguin Books, 2004.

\section{Praktisk handbok om sædanalysar}

Lars Björndahl, David Mortimer, Christopher L.R. Barratt et al.

A practical guide to basic laboratory andrology 336 s, tab, ill. New York, NY: Cambridge University Press, 2010. Pris USD 59 ISBN 978-0-521-73590-2

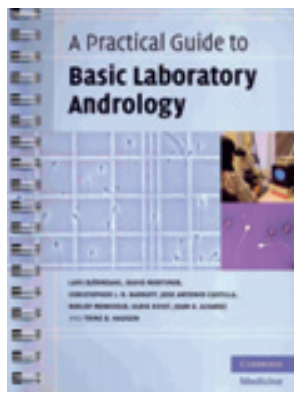

Dette er ei laboratoriehandbok for andrologiske laboratorium, fertilitetsklinikkar, klinikarar og andre fagfolk med interesse for mannleg fertilitet.

Forfattarane har til hensikt å betre standardiseringa og kvaliteten på

sædvurderingar og andre andrologiske laboratorieprosedyrer, samt å betre forståinga og dermed det kliniske bruksområdet av sædanalyseresultata og andre spermvurderingar.

Førekomsten av mannleg subfertilitet er aukande over heile verda. Ved utgreiing av den mannlege partnaren i eit subfertilt par vil sædanalysar gje viktig informasjon om mannen sin reproduktive funksjon. Rett bruk av sædanalyseresultata og hensiktsmessig fortolking, andre laboratorieundersøkingar og fysisk undersøking av mannen er av grunnleggjande betyding for å stille riktig diagnose og tilby eventuell vidare behandling.

Ved fertilitetsklinikkar vil resultata av sædprøvene nyttast til å velje den behandlingsforma som ein trur vil gje paret best sjanse til å lukkast. Sidan det ikkje eksisterer nokon absolutte grenseverdiar for val av behandling. og det faktum at kvaliteten på sædprepareringa også har innverknad på sluttresultatet, kan dette bidra til forvirring om sædsvaret si betyding for behandlingsutfallet. Til dømes er oligospermi og asthenospermi kvantitative termar som ikkje eignar seg som kvalitative termar av di dei i liten grad beskriv mannen sitt reproduksjonspotensiale. Forfattarane har difor utelate desse termane og oppmodar lesarane om å gjere det same. Dei ynskjer med dette å bidra til å fjerne misoppfatningar og mistydingar omkring normalområde og referanseverdiar som vert nytta ved sædanalysar.

Boka er oversiktleg og delt inn i 12 kapitlar. Etter ei grei innføring i grunnleggjande mannleg fysiologi og spermatogenese, tar forfattarane føre seg praktisk utføring av grunnleggjande og utvida sædanalysar (manuelle og dataassisterte), samt ulike funksjonstestar for spermiar. Dernest finn ein utførlege skildringar av korleis ein preparerer spermiar, frå ejakulat eller kirurgiske uttak, til bruk ved assistert befruktning, samt kryopreservering av spermiar og drift av spermbiobankar. Det er eigne kapittel om kvalitetssikring, akkreditering og risikostyring av andrologiske laboratorium, samt ei kort innføring i reproduksjonstoksikologi. Illustrasjonane er mange og gode. Fargebileta er av god kvalitet, men kunne med fordel vore plassert i tilslutnad til den aktuelle teksten.

Forfattarane gjev ein grundig gjennomgang av den vitskaplege bakgrunnen for dei ulike analysane og metodane som vert skildra, etterfølgd av grunngjevne fortolkingar av analyseresultat og metodeval. Dette kan vere nyttig i klinikarane sin dialog med laboratoria, men aller viktigast: i kommunikasjonen med pasientane og kva informasjon og råd dei bør få.

Eg kan trygt anbefale boka til andrologiske laboratorium og fertilitetsklinikkar. Den har pasienten i fokus og vektlegg kvalitet $\mathrm{i}$ alle ledd ved utføring av analyse- og behandlingsarbeid, samt gjev råd om korleis resultat kan presenterast i ein klinisk kontekst.

\section{Siren Skrede}

Seksjon for assistert befruktning Kvinneklinikken

Haukeland universitetssykehus

\section{Innsiktsfullt om risiko, formidling og folkehelse}

Peter Bennett, Kenneth Calman,

Sarah Curtis et al, red.

Risk communication and public health

2. utg. 339 s, ill. Oxford: Oxford University Press, 2010. Pris GBP 35

ISBN 978-0-19-956284-8

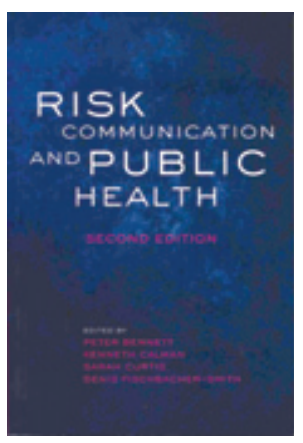

Boken omfatter 20 essays fra 33 forfattere inklusive de fire redaktørene. Som tittelen angir legger bidragsyterne hovedvekten på hvordan man kommuniserer risiko innen folkehelseområdet, hva som blir kommunisert, og til dels av og for hvem. Den er delt i tre hoveddeler som omfatter: Risikokommunikasjon og allmennhetens forståelse av usikkerhet innen folkehelseområdet, Risikokommunikasjon innen folkehelseområdet i praksis og Om organisering av forberedelse for, og reaksjoner ved trusler mot folkehelsen.

Første utgave kom i 1999. Redaktørene argumenterer for en ny omarbeidet utgivelse ved at risikobildet endrer seg. I dag er terrortrusselen stadig tilstedeværende, influensaepidemier har tiltrukket seg mer oppmersomhet, overvektsepidemien er blitt global, samtidig som tidligere trusler fortsatt er til stede. Nyhetsrapporteringen er blitt en 24-timers kontinuerlig prosess med øyeblikkelig oppdatering, og tiden for kontroll av holdbarheten i hva som blir rapportert, er blitt tilsvarende forkortet. Vi vet mer om hvordan risiko oppfattes, og om samspillet mellom tillit (eller fravær av denne) til myndigheter og egne oppfatninger. I essayene behandler forfatterne dette teoretisk og med konkrete eksempler som evakuering av storbyer ved åpenbare trusler, strålefarer i storbyer, vaksinasjoner og bivirkninger, matsikkerhet, barneulykker, medias rapportering og troverdighet. Eksemplene er for en stor del hentet fra Storbritannia, men er ikke mindre allmenngyldige av den grunn. Av de teoretiske betraktningene vil jeg spesielt fremheve føre-var-prinsippet som er behandlet i en egen artikkel.

Essayene dekker mange og ulike områder, og boken kan gi et sprikende inntrykk. Bidragene er trolig i liten grad samordnet annet enn etter de tre hoveddelene. Dette er ikke noen sterk innvending. Forfatterne er åpenbart meget familiære med sine områder, og redaktørene har en imponerende og bred bakgrunn. Den bør leses og befinne seg i hyllene hos dem som er ansvarlige for folkehelsearbeidet også i Norge, og ikke minst i ulike redaksjoner og hos nyhetsfor- 